\title{
Condensation origin for Neoproterozoic cap carbonates during deglaciation
}

\section{Martin J. Kennedy ${ }^{1}$ and Nicholas Christie-Blick ${ }^{2}$}

\author{
${ }^{1}$ Department of Earth and Environmental Sciences, University of \\ Adelaide, Adelaide, SA 5005, Australia \\ 2Department of Earth and Environmental Sciences and Lamont-Doherty \\ Earth Observatory of Columbia University, Palisades, New York 10964, \\ USA
}

Kula et al. (2012) reanalyze our sequence stratigraphic interpretation and carbon isotope data for the younger Neoproterozoic cap carbonate interval in the northeastern Amadeus Basin of central Australia (Kennedy and Christie-Blick, 2011), and conclude that they are incompatible. This conclusion is unwarranted.

Our paper focused on the interval between the upper part of the late Cryogenian Olympic Formation (glacial marine) and the lower part of the early Ediacaran Pertatataka Formation (a basin-wide marine siltstone representing post-glacial transgression). In relatively deep-water successions, such as the type section of the Olympic Formation (MS-11 in figure 3 of Kennedy and Christie-Blick, 2011), glacial deposits are sharply overlain by a several-meter-thick cap carbonate that is typical of Neoproterozoic successions worldwide, and that passes upward in turn to siltstone. Toward the depositional basin margin (northwestward), the cap carbonate expands into $\sim 175 \mathrm{~m}$ of nonmarine to marginal marine conglomerate, sandstone, siltstone, and marl, interspersed with thin, cap-like carbonate beds (Gaylad Sandstone and Waldo Pedlar Member of the Pertatataka Formation). Within that interval are three laterally traceable stratigraphic discontinuities (sequence boundaries) with up to tens of meters of erosional relief at proximal locations (MS-1 to MS-4 in figure 3 of Kennedy and Christie-Blick, 2011). The point of our article was to argue that such stratigraphic complexity, and the compositional variations with which they are associated, imply protracted sedimentation $\left(>10^{5} \mathrm{yr}\right)$ within the immediately post-glacial succession that hosts the cap carbonate. This contrasts with the geologically instantaneous time scales called for by some models for Neoproterozoic glaciation that consider the thin cap carbonate interval as a rapidly deposited geochemical whiting. A more complete history of base-level variation is preserved in proximal sections in much the same way as a Quaternary shelf record typically preserves such variations better than coeval deep-water facies.

Kula et al. replotted our carbon isotope data on a single graphic, using section MS-7 as a reference, and calculated implied rates and durations of sedimentation in comparison with that section. With the exception of two values in MS-10, and in spite of having assumed continuous accumulation at a constant rate for each section, the isotope values correspond surprisingly well with time windows implied by our interpretation of surfaces. Values between surfaces S1 and S2 vary from about $+4 \%$ o to $-1 \%$. Between $\mathrm{S} 2$ and $\mathrm{S} 3$, they range from about $-1 \%$ o to $-4 \%$. All but two values above surface $\mathrm{S} 3$ are within the range $-4 \%$ o to $-6 \%$. The two values of about $-2 \%$ in section MS-10 were obtained from immediately above surface S3, as mapped. While the existence of unconformities is not in doubt, our confidence in tracing stratigraphic discontinuities decreases in a basinward direction. In basinal sections (MS-7 to MS-11) it is necessary to rely on more subtle textural and compositional changes as proxies for correlatives of the surfaces recognized in basin margin sections (MS-1 to MS-6). A shift of no more than a few meters in the placement of surface S3 would take care of the anomalous isotopic values in MS-10 - the most distal of all sections except MS-11. Given a possible role for a range of diagenetic effects, the uncertain origin of marly limestone, and the broad demonstrated range of carbon isotope values from stratigraphically comparable intervals in cap carbonates (Kennedy, 1996; Giddings and Wallace, 2009), we are puzzled that Kula et al. find our sequence stratigraphic interpretation incompatible with the isotopic data.

Kula et al. express concern about use of the term "condensation" for the cap carbonate because the full range of carbon isotope values is not present in MS-11. This observation is not especially pertinent for several reasons. (1) The presence of thin carbonate turbidites, numerous smallscale discontinuities, and chemical precipitates like $\mathrm{Mn}$ and Fe oxides in many examples of cap carbonates, including section MS-11, is inconsistent with the notion of a continuous record of time (Kennedy, 1996; Jiang et al., 2006). (2) At Cleary Creek in the same part of the Amadeus Basin, carbon isotope values at the base of the cap are as high as $0 \%$ (Kennedy et al., 2001). (3) Cap carbonates, with few exceptions, represent relatively deep-water or off-platform sedimentation. At stake, therefore, is the mechanism by which condensation is achieved: a combination of discontinuous sediment accumulation at the scale of millimeters and intermittent erosion or dissolution. At some locations, including MS-11, time is missing preferentially at the base of the cap.

Condensation also took place explicitly as a result of punctuated overall transgression, and not progradation. This is expressed by the overstep of post-glacial siltstone and marl across the pre-glacial Bitter Springs Formation in MS-1 to MS-6, and by the transgressive character of each sequence above surface S2. Abrupt basinward shifts in facies at S2, S3, and S4 are interpreted to represent the interplay of glacioeustasy and glacial isostatic rebound close to the grounding line of the ice sheet. The northeastern Amadeus Basin is unusual because the opportunity to observe such interactions is rarely possible in Neoproterozoic glacial successions.

\section{REFERENCES CITED}

Giddings, J.A., and Wallace, M.W., 2009, Sedimentology and C-isotope geochemistry of the 'Sturtian' cap carbonate, South Australia: Sedimentary Geology, v. 216, p. 1-14, doi:10.1016/j.sedgeo.2009.01.007.

Jiang, G., Kennedy, M.J., Christie-Blick, N., Wu, H., and Zhang, S., 2006, Stratigraphy, sedimentary structures, and textures of the late Neoproterozoic Doushantuo cap carbonate in South China: Journal of Sedimentary Research, v. 76, p. 978-995, doi:10.2110/jsr.2006.086.

Kennedy, M.J., 1996, Stratigraphy, sedimentology, and isotopic geochemistry of Australian Neo-proterozoic postglacial cap dolostones: Deglaciation, $\delta^{13} \mathrm{C}$ excursions, and carbonate precipitation: Journal of Sedimentary Research, v. 66 , p. $1050-1064$.

Kennedy, M.J., and Christie-Blick, N., 2011, Condensation origin for Neoproterozoic cap carbonates during deglaciation: Geology, v. 39, p. 319-322, doi:10.1130/G31348.1.

Kennedy, M.J., Christie-Blick, N., and Prave, A.R., 2001, Carbon isotopic composition of Neoproterozoic glacial carbonates as a test of paleoceanographic models for snowball Earth phenomena: Geology, v. 29, p. 1135-1138, doi:10.1130/0091-7613(2001)029<1135:CICONG>2.0.CO;2.

Kula, J., Metcalf, J.R., and Wilkinson, B.H., 2012, Condensation origin for Neoproterozoic cap carbonates during deglaciation: Comment: Geology, e265, doi:10.1130/G32688C.1. 